\title{
Ulikhet i helse og helsetjenestebruk hos nordiske barn etter foreldrenes utdannelse
}

\author{
Else-Karin Grøholt og Rannveig Nordhagen \\ Nasjonalt folkehelseinstitutt, Oslo \\ Korrespondanse: Else-Karin Grøholt, Avdeling for sykdomsårsaker, Nasjonalt folkehelseinstitutt, Postboks 4404 Nydalen, 0403 Oslo
}

\begin{abstract}
SAMMENDRAG
Med utgangspunkt i en nordisk undersøkelse av ca. 10000 barn i alderen 2-17 år har vi sett på forekomsten av astma, allergisk rhinitt og eksem med spesiell fokus på sammenhengen mellom barnets sykdom og foreldrenes utdannelse. Vi har også analysert sammenhengen mellom barnas bruk av helsetjenester (legekonsultasjoner og innleggelse i sykehus) og foreldrenes utdannelse. Total forekomst av kronisk sykdom var $14,5 \%$. Forekomsten av astma, allergisk rhinitt og eksem var henholdsvis $2,4 \%, 3,4 \%$ og $3,4 \%$. Barn med en eller flere av disse tre diagnosene utgjorde til sammen ca. halvparten av alle kronisk syke barn. Forekomsten av astma, allergisk rhinitt og eksem var høyest i familier der foreldrene hadde lav utdannelse sammenlignet med familier der foreldrene hadde høy utdannelse. Konsultasjon hos allmennpraktiker var uavhengig av foreldrenes utdannelse. Konsultasjon hos spesialist og innleggelse i sykehus hadde en omvendt sosial gradient på den måten at foreldre med høyest utdannelse hadde høyere forbruk av spesialisthelsetjeneste enn foreldre med lavest utdannelse mens en høyere andel barn av foreldre med lav utdannelse ble innlagt i sykehus sammenlignet med barn av foreldre med høy utdannelse. Funnene fra undersøkelsen viser at det er en sammenheng mellom lav utdannelse hos foreldrene og forekomsten av astma, allergisk rhinitt og eksem blant barn og at det også er en sammenheng mellom foreldrenes utdannelse og barnas bruk av helsetjenester.
\end{abstract}

\section{Grøholt E-K, Nordhagen R. Differences in health and use of health services among Nordic children according to parental education. Nor J Epidemiol 2002; 12 (1): 47-54.}

\section{ENGLISH SUMMARY}

The present study is based on data from approximately 10,000 children aged 2-17 years in the Nordic countries in 1996. We have analysed the association between the prevalence of asthma, allergic rhinitis and eczema among children and parental education. Furthermore we have analysed the association between utilisation of health services among children (consulting a doctor or being hospitalised) and parental education. Overall prevalence of chronic health conditions among children was $14.5 \%$. Asthma, allergic rhinitis and eczema were the most prevalent conditions, representing about half the prevalence of chronic health conditions in the survey. The prevalence of asthma, allergic rhinitis and eczema was higher in the less educated, compared to the higher educated families. GP use did not depend on parental education in any of the Nordic countries. However, whereas specialist use was associated with high parental education, a higher proportion of children in low-educated families was hospitalised. The data presented in this article show that there is a link between low parental education and the prevalence of asthma, allergic rhinitis and eczema among children, and furthermore that there is a link between parental education and children's use of health services in the Nordic countries.

\section{INNLEDNING}

Sett fra et folkehelseperspektiv er det mange grunner til at barns helse er viktig. Barn er en sårbar gruppe $\mathrm{i}$ samfunnet, og barns helse og velferd kan derfor på mange måter reflektere samfunnets evne og vilje til omsorg. Samtidig er barnet prisgitt sine omgivelser uten egen politisk innflytelse (1).

Sosial ulikhet i helse har primært vært dokumentert i den voksne befolkning, men er også rapportert hos barn. Noen vil til og med hevde at helse i barnealder kan forklare sosial ulikhet i voksenhelse (2-9). I følge
West forsvinner den sosiale gradienten i ungdomsårene, og "reetableres" i voksen alder $(8,10,11)$, men funnene har delvis blitt imøtegått av andre $(12,13)$.

Den britiske rapporten, "The Black Report" utgitt i 1982, påviste store helseforskjeller mellom ulike sosiale grupper (14). Rapporten ble senere publisert sammen med "The health divide" (15) og viste at selv om helsetilstanden var bedret på mange områder, hadde ulikhetene mellom sosialklassene heller tiltatt i løpet av de 40 årene som var gått siden det nasjonale helseog velferdssystemet i Storbritannia var innført. Rapporten var medvirkende til at et av hovedmålene til 
WHOs "Helse for alle i år 2000" var å redusere helseforskjellene mellom ulike sosialgrupper (16).

Erfaringer fra mange utviklingsland har vist at en allment tilgjengelig helsetjeneste for barn er viktig for å bedre den generelle helsetilstanden $\mathrm{i}$ en befolkning (17). I vår vestlige del av verden vil subjektive og objektive behov i tillegg til sosiale, økonomiske og psykologiske faktorer være medvirkende årsaker til om man velger å konsultere lege eller ikke. En grunnleggende prioritering må være å gi et tilbud til de som trenger det mest. I USA, der pasienten selv må dekke utgiftene ved helsetjenestebruk, enten via forsikring eller ved å betale selv, er det lett å forstå at dette ikke er mulig. Dårlig økonomi eller mangel på adekvat forsikring fører derfor til at barn ikke får den hjelpen de kanskje har behov for. En direkte sammenheng mellom foreldrenes inntekt og barn og unges tilgjengelighet til helsetjenester i USA er rapportert (18).

Den nordiske velferdsmodellen bygger på fred, demokrati, regulert arbeidsmarked og velferd for alle. Den vokste fram på 1930-tallet, og har skapt et godt samfunn i de nordiske land. Helsetjenesten har høy offentlig støtte, og tilgjengeligheten burde derfor $\mathrm{i}$ utgangspunktet være lik for alle samfunnsklasser. I tillegg har utdannelsesnivået generelt blitt høyere i alle de nordiske land. Det siste tiåret har imidlertid arbeidsløshet og nedskjæringer i offentlig sektor ført til spekulasjoner om barnefamilier har fått dårligere økonomiske vilkår, og at barnas levekår av denne grunn har forverret seg (19). Sosiale forskjeller i helse, både hos voksne og barn er påvist $i$ flere nordiske studier (3-5). Lite forskning har vært gjort på sammenhengen mellom sosialgruppe og bruk av helsetjeneste hos barn, og funnene er noe omstridte (20-25). Selv om det er allment kjent at barn er store forbrukere av helsetjenester, har tidligere studier i stor grad vært konsentrert om helsetjenesteforbruk i den voksne befolkningen.

Vi har tidligere sett på sammenhengen mellom sosioøkonomiske forhold, en rekke kroniske sykdommer og helsetjenestebruk hos barn $(26,27)$. I denne artikkelen har vi spesielt sett på diagnosegruppene astma, allergisk rhinitt og eksem. Vi har analysert sammenhengen mellom forekomsten av disse tre diagnosegruppene og foreldrenes utdannelse. I tillegg har vi analysert sammenhengen mellom barnets bruk av helsetjenester og foreldrenes utdannelse.

\section{MATERIALE OG METODE}

\section{Utvalg}

I 1996 ble det gjennomført en tverrsnittsundersøkelse av helse, levekår og livskvalitet hos barn i Norden. Alle de fem nordiske land deltok i studien; Norge, Sverige, Finland, Island og Danmark. Et randomisert utvalg av ca. 3000 barn i aldersgruppen 2-17 år i hvert land ble plukket ut fra befolkningsregisteret. Barnas foreldre fikk tilsendt et spørreskjema med bl.a. spørsmål om sykdom, sosiodemografiske faktorer og bruk av helsetjenester. Spørreskjemaet inneholdt også spørsmål relatert til foreldrenes helse og velferd.

Datainnsamlingen startet i mars 1996 i alle de fem nordiske land. Responsraten varierte fra $64,5 \%$ til $69 \%$, og var lavest i Norge. Totalt 10317 besvarte spørreskjemaer ble returnert, og danner grunnlaget $i$ analysene. Ca. $35 \%$ av barna besvarte spørreskjemaet sammen med foreldrene.

\section{Frafallsundersokelse}

Frafallsundersøkelse ble gjennomført i alle de nordiske land unntatt Island $(19,28)$. Hovedfunnene var at responsraten var høyest blant foreldre med høy utdannelse, høy inntekt samt i familier med to foreldre. I det norske utvalget fant man størst forskjell for mors utdannelse. Høyt utdannede mødre utgjorde ca. 26,5\% av totalpopulasjonen, men $32,2 \%$ av respondentene (28). I det svenske utvalget utgjorde enslige foreldre ca. $12 \%$ av respondentene, og ca. $20 \%$ av frafallet. Forskjellene var imidlertid ikke så store at de hadde betydning for analysene (19).

\section{Definisjoner}

Kronisk sykdom var definert som en tilstand som i vesentlig grad hadde påvirket barnets daglige liv $\mathrm{i}$ minst tre måneder det siste året. En liste med 13 ulike diagnoser ble presentert, og hver av diagnosene kunne klassifiseres som mild, moderat eller alvorlig. Barnet ble definert til å ha en kronisk sykdom hvis foreldrene svarte "ja" eller oppgav at sykdommen var av moderat eller alvorlig grad. Listen over kroniske sykdommer er gjengitt i tabell 1.

Alle de fem nordiske land var inkludert i studien; Norge, Sverige, Island, Finland og Danmark. Barna ble inndelt i tre alderskategorier: 1) 2-6 år, 2) 7-12 år og 3) 13-17 år.

Foreldrenes utdannelse ble kategorisert i fire grupper etter den av foreldrene med høyest utdannelse: 1) > 12 år, 2) 12 år, 3) 10-11 år og 4) $\leq 9$ år. Foreldrenes sivilstatus ble delt i to kategorier: 1) gift/samboer og 2) enslig. Bosted var inndelt i 3 grupper etter antall innbyggere: 1) storbyområde (>100 000 innbyggere), 2) tettsted (>3000 innbyggere) og 3) Mindre tettsted $(<3000$ innbyggere).

Tabell 1. Forekomst av kroniske sykdommer hos 10317 barn i alderen 2-17 år i de nordiske land 1996.

\begin{tabular}{lrr}
\hline Diagnostisk kategori & $\mathrm{n}$ & $\%$ \\
\hline Totalt & 1505 & 14,5 \\
Eksem & 355 & 3,4 \\
Astma & 234 & 3,4 \\
Allergisk rhinitt & 332 & 2,4 \\
Mage/ tarmplager & 142 & 1,4 \\
Synshemning & 137 & 1,2 \\
Psykiske/ nervøse plager & 77 & 0,6 \\
Overvekt & 71 & 0,8 \\
Hørselshemning & 65 & 0,7 \\
Talefeil & 65 & 0,5 \\
Hyperaktivitet & 52 & 0,4 \\
Diabetes & 20 & 0,2 \\
Epilepsi & 18 & 0,2 \\
Andre diagnoser & 330 & 3,0 \\
\hline
\end{tabular}


Helsetjenesteforbruk ble definert som legekonsultasjon (hos allmennpraktiker eller spesialist) eller innleggelse i sykehus. Konsultasjon hos allmennpraktiker eller spesialist ble målt ved spørsmålet "Har barnet $i$ løpet av de siste tre månedene søkt noen av de følgende? (helsestasjon eller skolehelsetjenesten skal ikke medregnes i spørsmålet)". En liste over ulike alternativer ble deretter forevist, inkludert konsultasjon hos 1) kommunelege/allmennpraktiserende lege eller 2) spesialistlege ved sykehus/poliklinikk eller privatpraksis. Telefonkonsultasjoner var ikke med i analysene. Vi så på om barnet hadde vært hos lege eller ikke, uavhengig av antall konsultasjoner siste tre måneder. Innleggelse i sykehus ble målt ved spørsmålet "Har barnet vært innlagt på sykehus i løpet av de siste 12 månedene?" Også i disse analysene så vi på tendensen til og ikke antall innleggelser siste 12 måneder.

\section{Statistikk}

Ujusterte analyser ble gjort ved hjelp av tabellanalyse og chi-kvadrat test. Pga. ulik populasjonstetthet i de fem nordiske land, ble veide analyser benyttet. Dette ble gjort ved hjelp av statistikkprogrammet Stata (29). Populasjonsstørrelsen (Sverige 8890 000, Island 270 000, Norge 4450 000, Finland 5150000 og Danmark 5330 000) ble dividert med antall respondenter i hvert land for å kunne beregne antall personer bak hver observasjon (30). De justerte analysene ble gjort ved hjelp av logistisk regresjon i SPSS (31). Assosiasjonen mellom avhengig og uavhengig variabel er gitt ved odds ratio (OR) med 95\% konfidensintervall (KI). Referansekategorien har OR $=1$ og ingen KI.
Avhengige variable i den første analysen var henholdsvis astma, allergisk rhinitt og eksem hos barnet analysert $i$ tre ulike modeller. Uavhengige variable $i$ alle tre modellene var land, barnets alder, kjønn og bosted samt foreldrenes utdannelse og sivilstatus.

Avhengige variable $\mathrm{i}$ den andre analysen var barnets bruk av allmennpraktiker og spesialist siste tre måneder eller innleggelse i sykehus siste 12 måneder, analysert i tre ulike modeller. Uavhengige variable var kronisk sykdom hos barnet (definert i denne analysen som astma, allergisk rhinitt og/ eller eksem) samt de samme uavhengige variablene som i den første analysen.

Uavhengige variable med p-verdi $>0,25 \%$ ble ekskludert fra analysemodellene. Interaksjoner med pverdi $>0,5 \%$ ble også eksludert.

\section{Resultater}

Totalforekomsten av kroniske sykdommer var 14,5\% (tabell 1). Astma, allergisk rhinitt og eksem var de største diagnosegruppene, og utgjorde til sammen rundt halvparten av alle kronisk syke barn, eller ca. 8\% av totalpopulasjonen. Forekomsten av astma, allergisk rhinitt og eksem var henholdsvis 2,4\%, 3,4\% og 3,4\%. Tabell 2 viser sammenhengen mellom forekomsten av astma, allergisk rhinitt og eksem og de uavhengige variablene i modellen. Vi ser at forekomsten av allergisk rhinitt og eksem varierte mellom de nordiske land. Forekomsten av allergisk rhinitt var for eksempel lavest i Sverige og Danmark. Forekomsten av astma var ikke signifikant forskjellig i de fem nordiske land.

Tabell 2. Forekomst av astma, allergisk rhinitt og eksem hos barn i alderen 2-17 år i de nordiske land 1996.

\begin{tabular}{|c|c|c|c|c|c|c|c|c|c|c|c|c|c|c|c|}
\hline & \multicolumn{5}{|c|}{ Astma } & \multicolumn{5}{|c|}{ Allergisk rhinitt } & \multicolumn{5}{|c|}{ Eksem } \\
\hline & $\mathrm{N}$ & $\%$ & p-verdi & OR & CI $(95 \%)$ & $\mathrm{N}$ & $\%$ & p-verdi & OR & CI $(95 \%)$ & $\mathrm{N}$ & $\%$ & p-verdi & OR & CI $(95 \%)$ \\
\hline Totalt & 234 & 2,4 & & & & 332 & 3,4 & & & & 355 & 3,4 & & & \\
\hline \multicolumn{16}{|l|}{ Land } \\
\hline Norge & 1780 & 2,5 & 0,426 & 1,00 & & 1780 & 3,8 & $<0,001$ & 1,00 & & 1780 & 3,2 & 0,005 & 1,00 & \\
\hline Sverige & 2125 & 2.4 & & 0.88 & $0.57-1.34$ & 2125 & 2.4 & & 0.59 & $0.40-0.87$ & 2125 & 3.0 & & 0.83 & $0.57-1.21$ \\
\hline Island & 1735 & 2,4 & & 1,00 & $0,64-1,56$ & 1735 & 3,0 & & 0,82 & $0,56-1,21$ & 1735 & 4,7 & & 1,47 & $1,03-2,10$ \\
\hline Finland & 1892 & 2,0 & & 0,76 & $0,48-1,21$ & 1892 & 5,7 & & 1,28 & $0,92-1,80$ & 1892 & 4,8 & & 1,42 & $0,99-2,02$ \\
\hline Danmark & 2053 & 2,9 & & 1,19 & $0,79-1,79$ & 2053 & 2,6 & & 0,65 & $0,44-0,95$ & 2053 & 3,0 & & 0,88 & $0,61-1,29$ \\
\hline \multicolumn{16}{|l|}{ Alder } \\
\hline $2-6$ år & 3126 & 2,7 & 0,628 & \multirow{3}{*}{\multicolumn{2}{|c|}{ Droppet fra modellen }} & 3126 & 1,3 & $<0,001$ & 1,00 & & 3126 & 4,0 & 0,033 & 1,00 & \\
\hline $7-12$ år & 3572 & 2,3 & & & & 3572 & 3,7 & & 2,49 & $1,74-3,56$ & 3572 & 3,6 & & 0,65 & $0,50-0,83$ \\
\hline 13-17 år & 2782 & 2,4 & & & & 2782 & 5,3 & & 4,01 & $2,82-5,71$ & 2782 & 2,7 & & 0,68 & $0,52-0,90$ \\
\hline \multicolumn{16}{|l|}{ Kjønn } \\
\hline Gutt & 4899 & 3,0 & 0,002 & 1,00 & & 4899 & 4,0 & 0,004 & 1,00 & & 4899 & 3,1 & 0,152 & 1,00 & \\
\hline Jente & 4593 & 1,9 & & 0,73 & $0,56-0,96$ & 4593 & 2,8 & & 0,69 & $0,54-0,87$ & 4593 & 3,7 & & 1,23 & $0,99-1,53$ \\
\hline \multicolumn{16}{|c|}{ Foreldrenes utdannelse } \\
\hline$>12$ år & 3749 & 2,1 & 0,044 & 1,00 & & 3749 & 2,4 & $<0,001$ & 1,00 & & 3749 & 2,7 & 0,015 & 1,00 & \\
\hline 12 år & 2611 & 2,7 & & 1,19 & $0,83-1,68$ & 2611 & 3,8 & & 1,18 & $0,88-1,58$ & 2611 & 3,5 & & 1,14 & $0,86-1,53$ \\
\hline $10-11$ år & 2016 & 2,2 & & 1,21 & $0,84-1,76$ & 2016 & 3,1 & & 1,00 & $0,72-1,38$ & 2016 & 4,4 & & 1,61 & $1,20-2,14$ \\
\hline$\leq 9$ år & 1068 & 3,7 & & 2,07 & $1,38-3,11$ & 1068 & 5,8 & & 1,44 & $1,01-2,05$ & 1068 & 3,7 & & 1,38 & $0,95-2,00$ \\
\hline \multicolumn{16}{|c|}{ Foreldrenes sivilstatus } \\
\hline Gift / samboer & 8353 & 2,3 & 0,061 & 1,00 & & 8353 & 3,1 & 0,001 & 1,00 & & 8353 & 3,2 & 0,003 & 1,00 & \\
\hline Enslig & 1169 & 3,8 & & 1,66 & $1,17-2,36$ & 1169 & 5,1 & & 1,47 & $1,08-1,99$ & 1169 & 5,1 & & 1,66 & $1,24-2,23$ \\
\hline \multicolumn{16}{|l|}{ Bosted } \\
\hline Liten kommune & 2979 & 2,6 & 0,509 & \multirow{3}{*}{\multicolumn{2}{|c|}{ Droppet fra modellen }} & 2979 & 3,3 & 0,933 & \multirow{3}{*}{\multicolumn{2}{|c|}{ Droppet fra modellen }} & 2979 & 3,5 & 0,921 & \multirow{3}{*}{\multicolumn{2}{|c|}{ Droppet fra modellen }} \\
\hline Mindre tettsted & 3541 & 2,2 & & & & 3541 & 3,3 & & & & 3541 & 3,4 & & & \\
\hline By & 2929 & 2,7 & & & & 2929 & 3,5 & & & & 2929 & 3,5 & & & \\
\hline
\end{tabular}

Kolonnene viser variabelnavn med kategori, antall personer i hver kategori, prosent med astma, allergisk rhinitt eller eksem og p-verdi for forskjellen mellom kategoriene (ujusterte analyser). De to siste kolonnene under hver diagnosegruppe viser justert odds ratio (OR) med $95 \%$ konfidensintervall (CI) basert på logistisk regresjon. 
Forekomsten av astma og allergisk rhinitt var mindre blant jenter, mens forekomsten av eksem var uavhengig av barnets kjønn. Allergisk rhinitt hadde høyere forekomst $\mathrm{i}$ den eldste sammenlignet med den yngste aldersgruppen ( $\mathrm{OR}=4,01, \mathrm{CI}=2,82-5,71)$, mens eksem hadde lavere forekomst $\mathrm{i}$ den eldste sammenlignet med den yngste aldersgruppen $(\mathrm{OR}=0,68$, $\mathrm{CI}=0,52-0,90)$. Forekomsten av både astma, allergisk rhinitt og eksem var uavhengig av bosted. Alle tre diagnosegruppene hadde høyere forekomst blant barn av enslige foreldre sammenlignet med barn i to-foreldre familier.

\section{Forekomsten av astma, allergisk rhinitt og eksem og foreldrenes utdannelse}

Barn av foreldre med $\leq 9$ års utdannelse hadde høyere forekomst av astma og allergisk rhinitt sammenlignet med barn av foreldre med $>12$ års utdannelse $(\mathrm{OR}=$ $2,07, \mathrm{CI}=1,38-3,11$ og $\mathrm{OR}=1,44, \mathrm{CI}=1,01-2,05)$. Foreldre med 10-11 års utdannelse hadde ca. 1,6 ganger så stor odds for å ha et barn med eksem sammenlignet med foreldre med $>12$ års utdannelse $(\mathrm{CI}=$ 1,20-2,14). Resultater fra de ujusterte analysene viser at forekomsten av eksem var høyere også blant barn av foreldre med $\leq 9$ års utdannelse $(3,7 \%)$ sammenlignet med barn av foreldre med $>12$ års utdannelse (2,7\%), men forskjellen var ikke statistisk signifikant når vi kontrollerte for de andre variablene i modellen.

\section{Bruk av helsetjeneste}

Tabell 3 viser konsultasjon hos allmennpraktiker og spesialist siste 3 måneder og innleggelse i sykehus siste 12 måneder. Andelen barn som konsulterte allmennpraktiker og spesialist var høyere på Island $(27,8 \%$ versus 20,2\%) sammenlignet med de andre nordiske land. Innleggelse i sykehus var ikke signifikant forskjellig i de fem nordiske land. Konsultasjoner var mer vanlig i de yngste sammenlignet med de eldste aldersgruppene, men var uavhengig av barnets kjønn. Færre jenter enn gutter ble innlagt i sykehus $(\mathrm{OR}=0,81$, $\mathrm{CI}=0,68-0,96)$. Barn med astma, allergisk rhinitt eller eksem hadde oftere kontakt med allmennpraktiker $(\mathrm{OR}=1,30, \mathrm{CI}=1,20-1,41)$ og spesialist $(\mathrm{OR}=2,43$, $\mathrm{CI}=2,01-2,93)$ og ble dobbelt så ofte innlagt $\mathrm{i}$ sykehus $(C I=1,49-2,55)$ sammenlignet med barn uten kroniske sykdommer.

Mens andelen barn som konsulterte spesialist var høyere i byer sammenlignet med mindre kommuner $(\mathrm{OR}=1,40, \mathrm{CI}=1,19-1,63)$, var andelen barn som konsulterte allmennpraktiker og andelen barn som ble innlagt i sykehus uavhengig av barnets bosted. Konsultasjoner og innleggelser var uavhengig av foreldrenes sivilstatus.

Tabell 3. Konsultasjon hos lege (allmennpraktiker og spesialist) og innleggelse i sykehus hos barn i alderen 2-17 år i de nordiske land 1996.

\begin{tabular}{|c|c|c|c|c|c|c|c|c|c|c|c|c|c|c|c|}
\hline & \multicolumn{5}{|c|}{ Allmennpraktiker } & \multicolumn{5}{|c|}{ Spesialist } & \multicolumn{5}{|c|}{ Sykehus } \\
\hline & $\mathrm{N}$ & $\%$ & p-verdi & OR & CI $(95 \%)$ & $\mathrm{N}$ & $\%$ & p-verdi & OR & CI $(95 \%)$ & $\mathrm{N}$ & $\%$ & p-verdi & OR & CI (95\%) \\
\hline Totalt & 9852 & 20,4 & & & & 9706 & 14,4 & & & & 10155 & 6,3 & & & \\
\hline \multicolumn{16}{|l|}{ Land } \\
\hline Norge & 1774 & 24,2 & $<0,001$ & 1,00 & & 1709 & 12,3 & 0,003 & 1,00 & & 1917 & 6,4 & 0,018 & 1,00 & \\
\hline Sverige & 2125 & 16,3 & & 0,63 & $0,54-0,75$ & 2123 & 13,7 & & 1,27 & $1,03-1,56$ & 2130 & 5,5 & & 0,91 & $0,69-1,21$ \\
\hline Island & 1995 & 27,8 & & 1,21 & $1,02-1,43$ & 1969 & 20,2 & & 1,67 & $1,36-2,06$ & 1996 & 6,9 & & 0,95 & $0,72-1,27$ \\
\hline Finland & 1876 & 26,1 & & 1,13 & $0,95-1,33$ & 1839 & 16,2 & & 1,55 & $1,25-1,92$ & 1973 & 7,8 & & 1,17 & $0,88-1,54$ \\
\hline Danmark & 2082 & 18,5 & & 0,75 & $0,64-0,90$ & 2066 & 15,3 & & 1,39 & $1,13-1,79$ & 2139 & 6,0 & & 1,02 & $0,77-1,35$ \\
\hline \multicolumn{16}{|l|}{ Alder } \\
\hline 13-17 år & 2877 & 17,7 & $<0,001$ & 1,00 & & 3166 & 12,7 & $<0,001$ & 1,00 & & 2963 & 6,0 & $<0,001$ & 1,00 & \\
\hline $7-12$ år & 3644 & 16,0 & & 0,89 & $0,78-1,02$ & 3595 & 13,1 & & 1,19 & $1,02-1,38$ & 3756 & 4,9 & & 0,82 & $0,66-1,03$ \\
\hline $2-6$ år & 3219 & 27,5 & & 1,55 & $1,37-1,77$ & 2747 & 17,4 & & 1,42 & $1,22-1,65$ & 3309 & 8,0 & & 1,46 & $1,19-1,80$ \\
\hline \multicolumn{16}{|l|}{ Kjønn } \\
\hline Gutt & 5032 & 19,4 & 0,060 & 1,00 & & 4950 & 14,6 & 0,681 & Dropp & fra modellen & 5168 & 6,9 & 0,0127 & 1,00 & \\
\hline Jente & 4730 & 21,1 & & 1,10 & $0,99-1,21$ & 4672 & 14,2 & & & & 4888 & 5,5 & & 0,81 & $0,68-0,96$ \\
\hline \multicolumn{16}{|c|}{ Foreldrenes utdannelse } \\
\hline$>12$ år & 3798 & 20,0 & 0,529 & 1,00 & & 3749 & 15,7 & 0,001 & 1,00 & & 3900 & 4,5 & $<0,001$ & 1,00 & \\
\hline 12 år & 2707 & 21,4 & & 0,98 & $0,86-1,12$ & 2661 & 14,4 & & 0,88 & $0,75-1,02$ & 2770 & 8,2 & & 1,68 & $1,35-2,10$ \\
\hline $10-11$ år & 2100 & 20,4 & & 1,02 & $0,89-1,18$ & 2089 & 14,5 & & 0,87 & $0,74-1,03$ & 2178 & 6,7 & & 1,48 & $1,17-1,89$ \\
\hline$\leq 9$ år & 1101 & 19,3 & & 0,94 & $0,78-1,13$ & 1061 & 10,1 & & 0,66 & $0,53-0,84$ & 1154 & 7,1 & & 1,72 & $1,30-2,30$ \\
\hline \multicolumn{16}{|c|}{ Foreldrenes sivilstatus } \\
\hline Gift / samboer & 8596 & 20,0 & 0,026 & Dropp & fra modellen & 8473 & 14,4 & 0,826 & 1,00 & & 8845 & 6,1 & 0,108 & Dropp & fra modellen \\
\hline Enslig & 1196 & 23,1 & & & & 1173 & 14,2 & & 0,88 & $0,73-1,07$ & 1241 & 7,4 & & & \\
\hline \multicolumn{16}{|l|}{ Bosted } \\
\hline Liten kommune & 3084 & 19,0 & 0,141 & 1,00 & & 3011 & 12,4 & $<0,001$ & 1,00 & & 3158 & 6,1 & 0,567 & Dropp & fra modellen \\
\hline Mindre tettsted & 3567 & 21,1 & & 1,11 & $0,98-1,26$ & 3512 & 13,4 & & 1,14 & $0,98-1,33$ & 3695 & 6,5 & & & \\
\hline By & 3059 & 20,7 & & 1,12 & $0,98-1,28$ & 3044 & 18,3 & & 1,40 & $1,19-1,63$ & 3149 & 5,8 & & & \\
\hline \multicolumn{16}{|c|}{$\begin{array}{l}\text { Astma, allergisk rhinitt } \\
\text { eller eksem }\end{array}$} \\
\hline Nei & 7809 & 18,9 & $<0,001$ & 1,00 & & 7691 & 11,2 & $<0,001$ & 1,00 & & 7985 & 5,0 & $<0,001$ & 1,00 & \\
\hline $\mathrm{Ja}$ & 723 & 29,3 & & 1,30 & $1,20-1,41$ & 716 & 26,8 & & 2,43 & $2,01-2,93$ & 753 & 9,4 & & 1,95 & $1,49-2,55$ \\
\hline
\end{tabular}

Kolonnene viser variabelnavn med kategori, antall personer i hver kategori, prosent barn som har vært hos allmennpraktiker eller spesialist og p-verdi for forskjellen mellom kategoriene (ujusterte analyser). De to siste kolonnene under hver diagnosegruppe viser justert odds ratio (OR) med 95\% konfidensintervall (CI) basert på logistisk regresjon. 


\section{Barnas bruk av helsetjeneste og foreldrenes utdannelse}

Resultater fra både ujusterte og justerte analyser viser at konsultasjon hos allmennpraktiker var uavhengig av foreldrenes utdannelsesnivå, mens bruk av spesialist var lavere blant barn av foreldre med lav utdannelse $(\leq$ 9 år) sammenlignet med barn av foreldre med høy utdannelse (> 12 år) $(\mathrm{OR}=0,66, \mathrm{CI}=0,53-0,84)$. En større andel barn av foreldre med lav utdannelse ble innlagt i sykehus sammenlignet med barn av foreldre med høy utdannelse.

\section{DISKUSJON}

Resultater fra denne undersøkelsen viser at forekomsten av astma, allergisk rhinitt og eksem var henholdsvis $2,4 \%, 3,4 \%$ og $3,4 \%$, og utgjorde halvparten av alle kronisk syke barn. Forekomsten av alle tre diagnosegrupper var høyest i familier der foreldrene hadde lav sammenlignet med familier der foreldrene hadde høy utdannelse. Forekomsten var også høyest blant barn av enslige foreldre sammenlignet med barn i to-foreldre familier. Bruk av helsetjenester var høyere blant barn med en eller flere av disse diagnosene sammenlignet med barn uten kroniske sykdommer. Mens konsultasjon hos allmennpraktiker var uavhengig av foreldrenes utdannelse, var konsultasjon hos spesialist høyere i familier der foreldrene hadde høy sammenlignet med familier der foreldrene hadde lav utdannelse. Innleggelse i sykehus var mest vanlig i familier der foreldrene hadde lav sammenlignet med familier der foreldrene hadde høy utdannelse.

Studiepopulasjonen var randomisert, og det var derfor ingen vesentlige utvalgsskjevheter. Gjennomsnittlig responsrate var på $68 \%(64,5 \%-69 \%)$, og frafallundersøkelsen viste at foreldre med høy utdannelse, høy inntekt og familier med to foreldre hadde høyere svarprosent enn andre familier. Forskjellene var imidlertid ikke så store $(19,28)$.

Undersøkelsen er basert på foreldrenes subjektive opplysninger om barnets helse og bruk av helsetjenester, men ca. $35 \%$ av barna besvarte spørreskjemaet sammen med foreldrene. Sammenhengen mellom foredrenes utdannelse og forekomsten av astma, allergisk rhinitt eller eksem var imidlertid uavhengig av om barnet hadde vært med på å besvare spørreskjemaet eller ikke. Sammenhengen mellom foreldrenes utdannelse og bruk av spesialist og innleggelse i sykehus var også lik i disse to gruppene barn. Likevel må vi være klar over den feilkilden foreldrerapportering kan representere. På samme måte må vi også være klar over de begrensninger som ligger i selve studiedesignet. En tverrsnittsundersøkelse gir for eksempel ikke grunnlag for å trekke konklusjoner om årsak og virkning.

Datainnsamlingen ble foretatt $i$ vårhalvåret. Dette kan ha hatt betydning for prevalensen av astma, allergisk rhinitt og eksem ettersom dette er sykdommer som viser årstidsvariasjon. Datainnsamlingen ble imidlertid foretatt i samme tidsrom $i$ alle fem land.
Astma, allergisk rhinitt og eksem var de største diagnosegruppene $\mathrm{i}$ vår undersøkelse. Barn med en eller flere av disse diagnosene utgjorde rundt halvparten av alle kronisk syke barn i utvalget, og ca. $8 \%$ av totalpopulasjonen. De senere år har det vært rapportert om $ø$ øende forekomst av astma, og det har vært diskutert om økningen skyldes endrete diagnostiske kriterier eller økende morbiditet (32-34). Det har også vært rapportert om økende forekomst av allergisk rhinitt og eksem $(35,36)$.

De nordiske land har lang tradisjon for samarbeid over landegrensene og er svært like på mange måter. Forskjellene vi fant $\mathrm{i}$ forekomsten av allergisk rhinitt og eksem kan likevel være betinget $i$ en ulik forståelse av definisjonen på kronisk sykdom eller en ulik kultur for hva som aksepteres som sykdom. Likevel, den sosale strukturen i de nordiske land er nokså ensartet, karakterisert av et generelt høyt utdannelsesnivå. Dette kan forklare hvorfor sammenhengen mellom utdannelse og forekomsten av astma, allergisk rhinitt og eksem var lik i alle land, og at sammenhengen mellom utdannelse og spesialistbruk og mellom utdannelse og sykehusinnleggelser også var lik.

Pga. ulik organisering, er sammenligninger av helsetjenesten over landegrenser generelt vanskelig. De nordiske land har også ulik organisering av helsetjenesten, selv om mye likevel er likt (37). Dette kan gjenspeiles noe gjennom den variasjonen vi finner $\mathrm{i}$ konsultasjonsatferd mellom de enkelte land $i$ vår undersøkelse.

Sammenhengen mellom lav sosial status og forekomsten av astma, allergisk rhinitt og eksem har vært mindre tydelig enn for andre kroniske sykdommer. Allergi og eksem har i tidligere studier vist en omvendt sosial gradient med høyest forekomst i de høyeste sammenlignet med de laveste sosialgruppene $(38,39)$. Studier har også vist at forekomsten av astma og allergirelaterte tilstander var lavere $\mathrm{i} ø$ østeuropeiske land enn i vesteuropeiske (40-42). Forskjellen har bl.a. vært forklart ved at faktorer relatert til en "vestlig livsstil" har vært forbundet med en økt risiko for atopiske sykdommer $(40,41)$. Denne teorien har imidlertid vært noe omdiskutert, og de senere år har flere studier vist at også disse diagnosegruppene har høyest forekomst i de laveste sosialklassene $(43,44)$.

Sammenhengen mellom lav sosial status og bruk av helsetjeneste har også vært omdiskutert. Mens noen har funnet sosial ulikhet i bruken av helsetjenester, vil andre benekte dette (20-25). I vår undersøkelse fant vi at konsultasjon hos spesialist og innleggelse i sykehus hadde en omvendt sosial gradient på den måten at foreldre med høyest utdannelse hadde høyere bruk av spesialisthelsetjenester enn foreldre med lav utdannelse mens en høyere andel barn av foreldre med lav utdannelse ble innlagt i sykehus sammenlignet med barn av foreldre med høy utdannelse. Kanskje dette kan forklares ved at foreldre med lav utdannelse blir mer marginalisert $i$ et samfunn der utdannelsesnivået generelt er høyt? I Norden er vanligvis allmennpraktikeren inn- 
gangsport og henvisningsinstans til spesialisthelsetjenesten. Konsultasjon hos allmennpraktiker var uavhengig av foreldrenes utdannelse. Foreldre med høyest utdannelse er muligens flinkere til å overtale allmennlegen til å henvise videre til spesialist. Velutdannede foreldre har kanskje også lettere for å ta direkte kontakt med spesialist selv. I flere nordiske land har økende privatisering av spesialisthelsetjenesten gjort dette siste mye enklere. Økende egenandeler kan også være medvirkende årsak til den sosiale ulikheten i spesialistbruk $(45,46)$. Flere studier har vist at høye egenandeler er en hindring når utsatte grupper skal ta kontakt med helsevesenet $(21,45,47,48)$. At flere barn av foreldre med lav utdannelse ble innlagt i sykehus, kan kanskje forklares ved at foreldre med lav utdannelse venter lengre før de kontakter lege ved sykdom hos barnet. Dette kan medføre at barnet er sykere når det kommer til lege, og av denne grunn trenger å innlegges i sykehus. Barn av foreldre med lav utdannelse kan dessuten være mer sårbare og derfor sykere i utgangspunktet. Det kan også være at innleggende lege har lavere terskel for å legge inn barn fra familier der foreldrene hadde lavere sammenlignet med barn fra familier der foreldrene hadde høyere utdannelse.

Flere ulike teorier har vært fremmet og diskutert som årsak til det sosiale skillet i helse, men mange av teoriene er lite egnet til å forklare helseforskjeller hos barn (14,49-51). Vi vet at det er ulik atferd i ulike sosialgrupper med mer helseskadelig atferd i de laveste gruppene. Barn er prisgitt sine foreldre, og har liten mulighet til å unngå den helseskadelige effekten av for eksempel passiv røyking. Sett fra et atferdssynspunkt kan den sosialt betingete forskjellen i bruk av spesialist derfor antas å være en indirekte årsak til den forskjellen vi finner $i$ helse mellom barn av foreldre med ulik utdannelse. Studier har imidlertid vist at atferdsteorien kun forklarer litt av den sosiale forskjellen i helse. Mange vil derfor hevde at forhold som har med fordeling av inntekt og goder i samfunnet vil være bedre egnet til å forklare de observerte forskjellene i helse mellom ulike sosialgrupper. Denne teorien var bl.a. svært sentral i "The Black Report" (14).

Spencer hevder at det er den kumulative effekten av ulike risikofaktorer mer enn enkeltfaktorer som har betydning for den sosiale ulikheten i helse, og etterlyser forskning på dypereliggende årsaker $(51,52)$.

\section{KONKLUSJON}

Funnene fra denne undersøkelsen viser at det er en sammenheng mellom lav utdannelse hos foreldre og forekomsten av astma, allergisk rhinitt og eksem hos barn i de nordiske land. Funnene viser også at det er en sammenheng mellom foreldrenes utdannelse og barnas bruk av helsetjenester. En mulig tolking av resultatene kan være at lavutdannede foreldre blir mer marginaliserte $\mathrm{i}$ et samfunn der utdannelsesnivået generelt er høyt.

\section{REFERANSER}

1. Köhler L. Child public health. A new basis for child health workers. Eur J Public Health 1998; 8: 253-255.

2. Bor W, Najman JM, Andersen M, Morrison J, Williams G. Socioeconomic disadvantage and child morbidity: an Australian longitudinal study. Soc Sci Med 1993; 36 (8): 1053-1061.

3. Gissler M, Rahkonen O, Jarvelin MR, Hemminki E. Social class differences in health until the age of seven years among the Finnish 1987 birth cohort. Soc Sci Med 1998; 46 (12): 1543-1552.

4. Lundberg O. The impact of childhood living conditions on illness and mortality in adulthood. Soc Sci Med 1993; 36 (8): 1047-1052.

5. Peck MN. The importance of childhood socio-economic group for adult health. Soc Sci Med 1994; 39 (4): 553-562.

6. Rahkonen O, Lahelma E, Huuhka M. Past or present? Childhood living conditions and current socioeconomic status as determinants of adult health. Soc Sci Med 1997; 44 (3): 327-336.

7. van de Mheen H, Stronks K, Looman CW, Mackenbach JP. Role of childhood health in the explanation of socioeconomic inequalities in early adult health. J Epidemiol Community Health 1998; 52 (1): 15-19.

8. West P. Health inequalities in the early years: is there equalisation in youth? Soc Sci Med 1997; 44 (6): 833 858.

9. Marmot M, Wilkinson RG, eds. Social determinants of health. Oxford: Oxford University Press, 1999.

10. Macintyre S, West P. Lack of class variation in health in adolescence: an artefact of an occupational measure of social class? Soc Sci Med 1991; 32 (4): 395-402.

11. West P, Macintyre S, Annandale E, Hunt K. Social class and health in youth: findings from the west of Scotland twenty-07 study. Soc Sci Med 1990; 30 (6): 665-673.

12. Glendinning A, Love JG, Hendry LB, Shucksmith J. Adolescence and health inequalities: extensions to Macintyre and West. Soc Sci Med 1992; 35 (5): 679-687.

13. Goodman E. The role of socioeconomic status gradients in explaining differences in US adolescents' health. Am J Public Health 1999; 89 (10): 1522-1528.

14. Townsend PT, Davidson N. Inequalities in Health. The Black Report. London: Penguin Books, 1982. 
15. Townsend PT, Davidson N, Whitehead M. Inequalities in health: The Black Report, The health divide. London: Penguin Books, 1992.

16. Ministry of Social Affairs and Health. Health for All by the Year 2000. Revised Strategy for Cooperation. Helsinki: Ministry of Social Affairs and Health, Publication 9, 1993.

17. World Health Organisation. The World Health Report. Geneva: WHO, 1995.

18. Starfield B, Budetti PP. Child health status and risk factors. Health Serv Res 1985; 19 (6 Pt 2): 817-886.

19. Berntsson L. Health and well-being of children in the five Nordic countries in 1984 and 1996. Göteborg: Nordic School of Public Health, 2000.

20. Alberts JF, Sanderman R, Eimers JM, van den Heuvel WJ. Socioeconomic inequity in health care: a study of services utilization in Curacao. Soc Sci Med 1997; 45 (2): 213-220.

21. Barnett JR, Coyle P. Social inequality and general practitioner utilisation: assessing the effects of financial barriers on the use of care by low income groups. N Z Med J 1998; 111 (1061): 66-70.

22. Campbell SM, Roland MO. Why do people consult the doctor? Fam Pract 1996; 13 (1): 75-83.

23. Carr-Hill RA, Rice N, Roland M. Socioeconomic determinants of rates of consultation in general practice based on fourth national morbidity survey of general practices [see comments]. BMJ 1996; 312 (7037): 10081012.

24. Grimsmo A, Siem H. Factors affecting primary health care utilization. Fam Pract 1984; 1 (3): 155-161.

25. Krasnik A, Hansen E, Keiding N, Sawitz A. Determinants of general practice utilization in Denmark. Dan Med Bull 1997; 44 (5): 542-546.

26. Grøholt EK, Stigum H, Nordhagen R. Children with chronic health conditions in the Nordic countries in 1996 - influence of socio-economic factors. Ambulatory Child Health 2001; 7: 177-189.

27. Grøholt EK, Stigum H, Nordhagen R, Köhler L. Health service utilsation in the Nordic countries in $1996-$ influence of socio-economic factors among children with and without chronic health conditions. Eur J Public Health (in press).

28. Teigum HM. Barns helse og velferd 1996. Dokumentasjon og frafallsanalyse. 97/6. Statistics Norway, 1997.

29. Stata Statistical software: Release 7.0. College Station, TX: Stata Corporation, 2001.

30. Fokus 2000. Oslo: Kunnskapsforlaget, 2000.

31. Hosmer DW, Lemeshow S. Applied Logistic Regression. John Wiley, 1989.

32. Anderson HR, Butland BK, Strachan DP. Trends in prevalence and severity of childhood asthma [see comments]. BMJ 1994; 308 (6944): 1600-1604.

33. Crater SE, Platts-Mills TA. Searching for the cause of the increase in asthma. Curr Opin Pediatr 1998; 10 (6): 594-599.

34. Nystad W, Magnus P, Gulsvik A, Skarpaas IJ, Carlsen KH. Changing prevalence of asthma in school children: evidence for diagnostic changes in asthma in two surveys 13 yrs apart. Eur Respir J 1997; 10 (5): 10461051.

35. Jones NS, Carney AS, Davis A. The prevalence of allergic rhinosinusitis: a review. J Laryngol Otol $1998 ; 112$ (11): 1019-1030.

36. Butland BK, Strachan DP, Lewis S, Bynner J, Butler N, Britton J. Investigation into the increase in hay fever and eczema at age 16 observed between the 1958 and 1970 British birth cohorts. BMJ 1997; 315 (7110): 717721.

37. Kristiansen I, Pedersen K. Health care systems in the Nordic countries: More similar than different? Tidsskr Nor Loegeforen 2000; 120: 2023-2029.

38 Suarez-Varela MM, Gonzalez AL, Martinez Selva MI. Socioeconomic risk factors in the prevalence of asthma and other atopic diseases in children 6 to 7 years old in Valencia Spain. Eur J Epidemiol 1999; 15 (1): 35-40.

39. Williams HC, Strachan DP, Hay RJ. Childhood eczema: disease of the advantaged? BMJ 1994; 308 (6937): 1132-1135.

40. Heinrich J, Richter K, Magnussen H, Wichmann HE. Is the prevalence of atopic diseases in East and West Germany already converging? Eur J Epidemiol 1998; 14 (3): 239-245.

41. Heinrich J, Nowak D, Wassmer G, Jorres R, Wjst M, Berger J, et al. Age-dependent differences in the prevalence of allergic rhinitis and atopic sensitization between an eastern and a western German city. Allergy 1998; 53 (1): 89-93.

42. Heinrich J, Popescu MA, Wjst M, Goldstein IF, Wichmann HE. Atopy in children and parental social class. Am J Public Health 1998; 88 (9): 1319-1324.

43. Duran-Tauleria E, Rona RJ. Geographical and socioeconomic variation in the prevalence of asthma symptoms in English and Scottish children [see comments]. Thorax 1999; 54 (6): 476-481.

44. Halfon N, Newacheck PW. Childhood asthma and poverty: differential impacts and utilization of health services. Pediatrics 1993; 91 (1): 56-61. 
45. Elofsson S, Unden AL, Krakau I. Patient charges - a hindrance to financially and psychosocially disadvantaged groups seeking care. Soc Sci Med 1998; 46 (10): 1375-1380.

46. Westin S. New extra tax for the sick [In Norwegian]. Tidsskr Nor Lageforen 2000; 120 (6): 653.

47. Undersøkelse om omfanget av utgifter til helse-og sosialtjenester. Dokumentasjon og tabellrapport. 2000/45. 2000. Oslo-Kongsvinger: Statistisk sentralbyrå.

48. Nelson DE, Thompson BL, Bland SD, Rubinson R. Trends in perceived cost as a barrier to medical care, 1991-1996. Am J Public Health 1999; 89 (9): 1410-1413.

49. Dahl E. Social inequality in health - the role of the healthy worker effect. Soc Sci Med 1993; 36 (8): $1077-$ 1086.

50. Power C. Health and social inequality in Europe [see comments]. BMJ 1994; 308 (6937): 1153-1156.

51. Spencer N. Poverty and Child Health. Oxford: Radcliffe Medical Press, 1996.

52. Spencer N. Social gradients in health: why do they occur and what can paediatricians do about them? Ambulatory Child Health 2000; 6 (3): 191-202. 